\title{
CORRELATION OF PORTAL VEIN DIAMETER, SPLENOMEGALY AND THROMBOCYTOPAENIA WITH GASTRO-OESOPHAGEAL VARICES IN CIRRHOTIC PATIENTS
}

\author{
Krishan Oberoi ${ }^{1}$, Upasana ${ }^{2}$
}

${ }^{1}$ Associate Professor, Department of Medicine, Guru Nanak Dev Hospital, Amritsar.

${ }^{2}$ Lecturer, Department of Obstetrics \& Gynaecology, Guru Nanak Dev Hospital, Amritsar.

\section{ABSTRACT}

\section{BACKGROUND}

The word cirrhosis comes from the Greek word kirrhos, which means orange yellow. ${ }^{1}$ Cirrhosis is a chronic disease of the liver in which diffuse destruction and regeneration of hepatic parenchymal cells and diffuse increase in connective tissue has resulted in disorganisation of the lobular architecture, which leads to various complications such as portal hypertension and its sequelae including gastro-oesophageal varices and splenomegaly, thrombocytopaenia, etc.

The aim of this study is to study the correlation of portal vein diameter, splenomegaly and thrombocytopaenia with gastrooesophageal varices in cirrhotic patients.

\section{MATERIALS AND METHODS}

This is an observational study including 100 patients of cirrhosis attending OPD/ admitted in various wards of Guru Nanak Dev Hospital and allied group of hospitals attached to Government Medical College, Amritsar.

\section{RESULTS}

Most of the patients in our study had grade II oesophageal varices (29\%) and the most common age distribution in patients with grade II varices is 25 - 75 years. In our study, it is seen that portal vein diameter increases with development of gastro-oesophageal varices ( $p$-value $<0.001$ ). Spleen size increases with formation of gastro-oesophageal varices ( $p$-value $<0.001$ ). Platelet count decreases with the development of gastro-oesophageal varices ( $\mathrm{p}$-value $<0.001$ ).

\section{CONCLUSION}

It is concluded from our study that there is a positive correlation between portal vein diameter and splenomegaly with gastrooesophageal varices and an inverse relationship between thrombocytopaenia and gastro-oesophageal varices.

\section{KEYWORDS}

Cirrhosis, Splenomegaly, Thrombocytopaenia.

HOW TO CITE THIS ARTICLE: Oberoi K, Upasana. Correlation of portal vein diameter, splenomegaly and thrombocytopaenia with gastro-oesophageal varices in cirrhotic patients. J. Evolution Med. Dent. Sci. 2017;6(83):5806-5810, DOI: $10.14260 /$ jemds/2017/1260

\section{BACKGROUND \\ The definition of cirrhosis remains morphological, described by World Health Organisation (WHO) in 1978 as: "a diffuse process characterised by fibrosis and the conversion of normal liver architecture into structurally abnormal nodules." 2 \\ Cirrhosis is a chronic disease of the liver, in which diffuse destruction and regeneration of hepatic parenchymal cells and diffuse increase in connective tissue has resulted in disorganisation of the lobular architecture. The triad of parenchymal necrosis, regeneration and scarring is always present in cirrhosis regardless of individual clinical manifestations. ${ }^{3}$ \\ Clinical features of cirrhosis derive from morphological alterations and usually reflect severity of hepatic damage rather than the aetiology of the underlying liver disease.}

'Financial or Other Competing Interest': None.

Submission 09-09-2017, Peer Review 02-10-2017,

Acceptance 09-10-2017, Published 16-10-2017.

Corresponding Author:

Dr. Krishan Oberoi,

\#13-C, Mata Kaulan Marg,

Kashmir Avenue,

Amritsar-143001, Punjab.

E-mail: drkrishanoberoi@gmail.com

DOI: $10.14260 /$ jemds $/ 2017 / 1260$
Fibrosis and distorted vasculature lead to portal hypertension and its sequelae including gastro-oesophageal varices and splenomegaly. Ascites and hepatic encephalopathy result from both portal hypertension and hepatocellular insufficiency. Thrombocytopaenia occurs as a result of hypersplenism and in alcoholic patients due to direct bone marrow suppression by ethanol. Diminished protein synthesis can lead to reduced production of factors I, II, V, VII, IX and X. The main causes of cirrhosis are alcoholic liver disease (ALD), hepatitis B (HBV), hepatitis C (HCV), nonalcoholic steatohepatitis (NASH), haemochromatosis, autoimmune hepatitis (AIH), primary biliary cirrhosis (PBC) and primary sclerosing cholangitis (PSC). 4,5

The natural history of cirrhosis can be divided into a preclinical and a subsequent clinical phase. The preclinical phase is usually prolonged over several years; once clinical events occur such as ascites, hepatic encephalopathy, variceal bleeding or the development of hepatocellular carcinoma, the remaining course of the disease is much shorter and usually fatal. 6

Portal hypertension is the most common and lethal complication of chronic liver disease. Portal hypertension is defined as an increase in portal pressure, in which the pressure gradient between the portal vein and inferior vena cava (the portal pressure gradient) is increased above the upper normal limit of $5 \mathrm{mmHg}$. The clinical significance increases when portal pressure increases above $10 \mathrm{mmHg}$ 
(formation of varices) and above $12 \mathrm{mmHg}$ (variceal bleeding and ascites).7,8,9

Development of oesophageal varices is one of the major complications of portal hypertension. After varices have developed, about one-third of patients die of gastrooesophageal variceal bleeding. The risk of initial bleeding from varices is $25 \%-35 \%$ within two years with first bleeding episodes mostly occur within one year after detection of varices. ${ }^{10,11,12}$ The reported mortality from first episode of variceal bleeding ranges from $40 \%-70 \% .^{13}$

Cirrhosis is associated with both quantitative and qualitative abnormalities of platelets. ${ }^{14}$ Approximately, 40\% of cirrhotic patients have abnormal prolongation of the bleeding time to values of more than 10 minutes and platelet counts less than $100,000 / \mathrm{mm}^{3}$. Causes of thrombocytopaenia in cirrhosis may be: - 1) Portal hypertension-induced splenic sequestration; 2) Alterations in thrombopoietin; 3) Bone marrow suppression mediated by toxins (e.g. alcohol, hepatitis B and C); 4) Consumptive coagulopathy; 5) Increased blood loss (e.g. haemorrhage).

Recently, the Baveno III consensus conference on portal hypertension recommended that all cirrhotic patients should be screened for the presence of oesophageal varices when liver cirrhosis is diagnosed. ${ }^{15}$

Upper gastrointestinal endoscopy is the most commonly used method to detect varices. Endoscopic grading of oesophageal varices is subjective. Various criteria have been used to standardise the reporting of oesophageal varices as those compiled by the Japanese Research Society for Portal Hypertension, which include red colour signs, colour of the varix, form (size) of the varix and location of the varix. ${ }^{16,17}$

Although, varices may form in any location along the tubular gastrointestinal tract, they most often appear in the distal few centimetres of the oesophagus. ${ }^{9,18}$

Gastric varices were graded according to classification proposed by Sarin et al ${ }^{19}$ for gastro-oesophageal varices (GOV) and isolated gastric varices (IGV).

The current consensus is that all patients with cirrhosis of the liver should be screened for oesophageal varices by endoscopy. In patients in whom no varices are detected on initial endoscopy, endoscopy should be repeated in 2 to 3 years to look for varices. If small varices are detected on the initial endoscopy, endoscopy should be repeated in 1 to 2 years.

Thrombocytopaenia and splenomegaly are independent predictors of large oesophageal varices in Cirrhosis. There is evidence that with increase in portal vein diameter, splenomegaly and thrombocytopaenia there is increase in the chance of formation of gastro-oesophageal varices. Thus, these can be used as non-invasive predictors of presence of oesophageal varices and guide for selecting patients for endoscopic evaluation.

Sarwar et $\mathrm{al}^{20}$ reported that patients with portal vein diameter more than $11 \mathrm{~mm}$ are more likely to have oesophageal varices. Another study by Dib et $\mathrm{al}^{21}$ showed that oesophageal varices developed when the portal vein diameter exceeded $13 \mathrm{~mm}$.

Sarangapani A et $\mathrm{al}^{22}$ in a study analysed 106 patients with chronic liver disease for prediction of large oesophageal varices. Results showed that incidence of large varices was seen in $41 \%$ cases. Sotoudehmanesh $\mathrm{R}$ et $\mathrm{al}^{23}$ in a case control study discussed the role of Endoscopic Ultrasonography in patients with Chronic Liver disease (CLD). The study concluded that splenic and portal vein dilation and thrombocytopaenia significantly correlated with variceal bleeding $(\mathrm{p}<0.05)$.

Elliot Schwarzenberger et al ${ }^{24}$ conducted a retrospective analysis of 137 patients with cirrhosis over the age of 18 that underwent screening endoscopy for varices. They concluded that the platelet count/ spleen diameter ratio with a cut-off value of 909 may not be sufficiently accurate in predicting the presence of oesophageal varices. Upper GI endoscopy remains the method of choice to screen for the presence of varices.

\section{Aims and Objectives}

To find out correlation of portal vein diameter, splenomegaly and thrombocytopaenia with gastro-oesophageal varices in cirrhotic patients.

\section{MATERIALS AND METHODS}

This is an observational study including 100 patients of cirrhosis attending OPD/ admitted in various wards of Guru Nanak Dev Hospital and allied group of hospitals attached to Government Medical College, Amritsar. After obtaining informed consent, the patients were subjected to detailed history and clinical examination.

Each patient was subjected to investigations which included platelet count, ultrasound to detect portal vein diameter and spleen size and oesophago-gastroduodenoscopy to grade gastric and oesophageal varices. The results of this study were systematically collected and statistically analysed.

\section{According to Paquet ${ }^{18}$ Grading System Varices were graded as-}

Grade 0- No varices.

Grade I- Varices, disappearing with insufflation.

Grade II- Larger, clearly visible, usually straight varices, not disappearing with insufflation.

Grade III- More prominent varices, locally coil-shaped and partly occupying the lumen.

Grade IV- Tortuous, sometimes grape-like varices occupying the oesophageal lumen.

Gastric varices were graded according to classification proposed by Sarin et al ${ }^{19}$ for gastro-oesophageal varices (GOV) and isolated gastric varices (IGV).

\section{Inclusion Criteria}

- Individuals of age $>18$ years.

- Patients of cirrhosis with portal hypertension.

\section{Exclusion Criteria}

- $\quad$ Patients with advanced cirrhosis (Child-Pugh Class C).

- Patients with human immunodeficiency virus (HIV) infection.

- Patients with hepatocellular carcinoma.

- Patients with portal vein thrombosis.

- Patients with current alcohol abuse.

- Previous or current treatment with B-blockers, diuretics and other vasoactive drugs.

- Patients with severe or unstable cardiovascular disease and pulmonary disease.

- Patients with clinically significant renal or hepatic disease or dysfunction,

- $\quad$ Patients with haematological disorders. 
Upper gastrointestinal endoscopy was done with fibreoptic video endoscope manufactured by Pentax. The results were systematically recorded and analysed. The ANOVA with post-hoc test has been used for statistical analysis. The SPSS software has been used in performance of statistical analysis. After evaluating patients for above parameters, treatment for cirrhosis was initiated according to the need of the patient.

\section{RESULTS}

A total of 100 patients were selected for the study. Among them, 74 patients $(74 \%)$ were males and 26 patients $(26 \%)$ were females. Most of the patients (29\%) had grade II oesophageal varices, $27 \%$ had grade III varices, $25 \%$ had grade IV varices and $19 \%$ had grade I varices. The distribution of patients according to grades of oesophageal varices is shown in Table I.

\begin{tabular}{|c|c|c|}
\hline $\begin{array}{c}\text { Grade of Oesophageal } \\
\text { Varices }\end{array}$ & $\begin{array}{c}\text { Number of } \\
\text { Patients }\end{array}$ & Percentage (\%) \\
\hline I & 19 & 19 \\
\hline II & 29 & 29 \\
\hline III & 27 & 27 \\
\hline IV & 25 & 25 \\
\hline Total & $\mathbf{1 0 0}$ & $\mathbf{1 0 0}$ \\
\hline \multicolumn{2}{|c|}{ Table I. Distribution of Grades of Oesophageal Varices } \\
\hline
\end{tabular}

Mean age of the patients with grade I oesophageal varices was $47.58 \pm 11.442$ years, mean age of the patients with grade II varices was $46.45 \pm 11.44$ years, mean age of the patients with grade III varices was $47.56 \pm 13.12$ years and mean age of the patients with grade IV varices was $48.72 \pm$ 15.13 years ranging from 14 to 85 years as shown in Table II.

\begin{tabular}{|c|c|c|c|c|}
\hline $\begin{array}{l}\text { Grade of } \\
\text { Oeso- } \\
\text { phageal } \\
\text { Varices }\end{array}$ & $\begin{array}{c}\text { Number } \\
\text { of } \\
\text { Patients }\end{array}$ & $\begin{array}{l}\text { Range } \\
\text { (Years) }\end{array}$ & $\begin{array}{c}\text { Mean Age } \\
\text { (Years) } \\
\text { (mean } \pm \text { SD) }\end{array}$ & $\begin{array}{c}\text { Significance } \\
\text { (p value) }\end{array}$ \\
\hline I & 19 & $30-65$ & $47.58 \pm 11.44$ & \multirow{4}{*}{$\begin{array}{c}\mathrm{p}=0.937 \\
(\mathrm{NS})\end{array}$} \\
\hline II & 29 & $25-75$ & $46.45 \pm 11.44$ & \\
\hline III & 27 & $25-82$ & $47.56 \pm 13.12$ & \\
\hline IV & 25 & $14-85$ & $48.72 \pm 15.13$ & \\
\hline & & stribut & $\begin{array}{l}\text { n with the Gra } \\
\text { al Varices }\end{array}$ & ing of \\
\hline
\end{tabular}

Correlation of Portal Vein Diameter with the Grading of Oesophageal Varices

It was observed from the study that the mean portal vein diameter of the patients with grade I oesophageal varices was $13.16 \pm 0.61 \mathrm{~mm}$ with grade II oesophageal varices was 14.59 $\pm 0.56 \mathrm{~mm}$ with grade III oesophageal varices was $16.39 \pm$ $0.69 \mathrm{~mm}$ and with grade IV oesophageal varices was $19.02 \pm$ $0.99 \mathrm{~mm}$.

From statistical analysis, it was also found that there was a positive correlation between portal vein diameter and grading of the oesophageal varices and this correlation was found to be statistically significant $(\mathrm{p}<0.001)$ that meant that when portal vein diameter increased oesophageal varices also increased in size as shown in Table III.

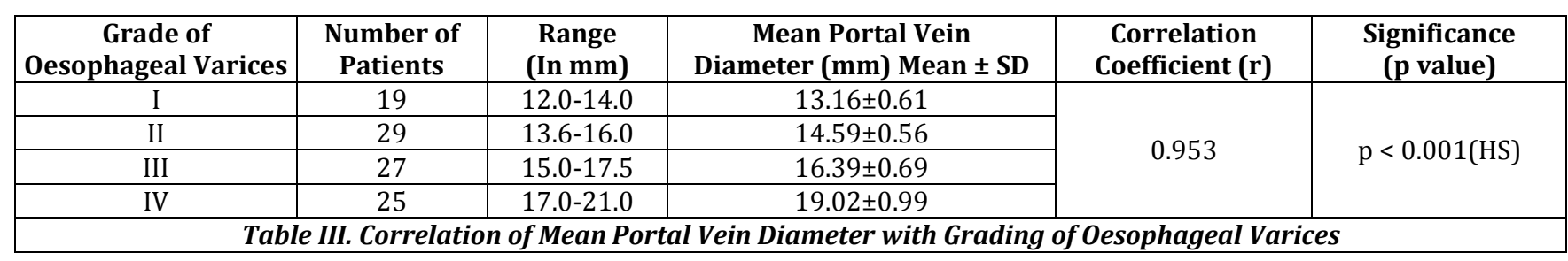

\section{Correlation of Spleen Size with the Grading of} Oesophageal Varices

It was observed from the study that the mean spleen size of the patients with grade I oesophageal varices was $12.05 \pm$ $0.67 \mathrm{~cm}$ with grade II oesophageal varices was $14.33 \pm 0.93$ $\mathrm{cm}$ with grade III oesophageal varices was $16.35 \pm 1.03 \mathrm{~cm}$ and with grade IV oesophageal varices was $19.10 \pm 1.16 \mathrm{~cm}$.

From statistical analysis, it was also found that there was a positive correlation between spleen size and grading of the oesophageal varices and this correlation was found to be statistically significant $(\mathrm{p}<0.001)$ that concluded that when spleen size increased, oesophageal varices also increased in size as shown in Table IV.

\begin{tabular}{|c|c|c|c|c|c|}
\hline 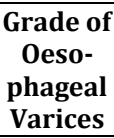 & $\begin{array}{c}\text { Number } \\
\text { of } \\
\text { Patients }\end{array}$ & $\begin{array}{l}\text { Range } \\
(\text { in } \mathrm{cm})\end{array}$ & $\begin{array}{c}\text { Mean } \\
\text { Spleen } \\
\text { Size }(\mathrm{cm}) \\
\text { Mean } \pm \text { SD }\end{array}$ & $\begin{array}{c}\text { Correlation } \\
\text { Coefficient } \\
\text { (r) }\end{array}$ & $\begin{array}{l}\text { Significance } \\
\text { (p value) }\end{array}$ \\
\hline I & 19 & $\begin{array}{l}11.0- \\
13.0\end{array}$ & $\begin{array}{c}12.05 \pm \\
0.67\end{array}$ & \multirow{4}{*}{0.941} & \multirow{4}{*}{$\mathrm{p}<0.001(\mathrm{~S})$} \\
\hline II & 29 & $\begin{array}{l}12.0- \\
16.0\end{array}$ & $\begin{array}{c}14.33 \pm \\
0.93\end{array}$ & & \\
\hline III & 27 & $\begin{array}{l}14.5- \\
20.0\end{array}$ & $\begin{array}{c}16.35 \pm \\
1.03\end{array}$ & & \\
\hline IV & 25 & $\begin{array}{l}17.0- \\
21.0\end{array}$ & $\begin{array}{c}19.10 \pm \\
1.16\end{array}$ & & \\
\hline \multicolumn{6}{|c|}{$\begin{array}{l}\text { Table IV. Correlation of Mean Spleen } \\
\text { Size with Grading of Oesophageal Varices }\end{array}$} \\
\hline
\end{tabular}

Correlation of Thrombocytopaenia with the Grading of Oesophageal Varices

From the above study, it was observed that mean platelet count in grade I oesophageal varices was $142568.42 \pm$ $6640.369 / \mathrm{mm}^{3}$, in grade II oesophageal varices was $109272.41 \pm 9567.16 / \mathrm{mm}^{3}$, in grade III oesophageal varices was $79288.89 \pm 5506.94 / \mathrm{mm}^{3}$ and in grade IV oesophageal varices was $45156.00 \pm 7032.43 / \mathrm{mm}^{3}$.

Statistical analysis showed an inverse relation between the platelet count and grading of oesophageal varices. It was a statistically significant correlation with $\mathrm{p}$-value $<0.001$. It also suggested that as the platelet count decreased, grading of oesophageal varices increased as shown in Table V.

\begin{tabular}{|c|c|c|c|c|c|}
\hline $\begin{array}{c}\text { Grade } \\
\text { of Oeso- } \\
\text { phageal } \\
\text { Varices }\end{array}$ & $\begin{array}{l}\text { Number } \\
\text { of } \\
\text { Patients }\end{array}$ & $\begin{array}{c}\text { Range } \\
\text { (in/mm3) }\end{array}$ & $\begin{array}{c}\text { Mean } \\
\text { Platelet } \\
\text { Count } \\
(/ \mathrm{mm} 3) \\
\text { Mean } \pm \text { SD }\end{array}$ & $\begin{array}{c}\text { Correlation } \\
\text { Co- } \\
\text { efficient } \\
\text { (r) }\end{array}$ & $\begin{array}{l}\text { Significance } \\
\text { (p value) }\end{array}$ \\
\hline I & 19 & $\begin{array}{l}120000- \\
152000\end{array}$ & $\begin{array}{c}142568.42 \pm \\
6640.37\end{array}$ & \multirow{4}{*}{-0.961} & \multirow{4}{*}{$\begin{array}{c}\mathrm{P} \\
<0.001(\mathrm{~S})\end{array}$} \\
\hline II & 29 & $\begin{array}{l}80000- \\
129000 \\
\end{array}$ & $\begin{array}{c}109272.41 \pm \\
9567.16\end{array}$ & & \\
\hline III & 27 & $\begin{array}{l}70000- \\
90000\end{array}$ & $\begin{array}{l}79288.89 \pm \\
5506.94\end{array}$ & & \\
\hline IV & 25 & $\begin{array}{c}36000- \\
58000\end{array}$ & $\begin{array}{l}45156.00 \pm \\
7032.43\end{array}$ & & \\
\hline \multicolumn{6}{|c|}{$\begin{array}{l}\text { Table V. Correlation of Mean Platelet } \\
\text { ount with Grades of Oesophageal Varices }\end{array}$} \\
\hline
\end{tabular}


It was observed that concomitant gastric varices along with oesophageal varices were present only in $2(2 \%)$ patients in our study.

\begin{tabular}{|c|c|c|c|c|c|c|c|}
\hline Number & $\begin{array}{c}\text { Age } \\
\text { (Years) }\end{array}$ & Gender & $\begin{array}{c}\text { Platelet Count } \\
\text { (/mm3) }\end{array}$ & $\begin{array}{c}\text { Spleen size } \\
\text { (cm) }\end{array}$ & $\begin{array}{c}\text { Portal Vein Diameter } \\
\text { (mm) }\end{array}$ & $\begin{array}{c}\text { Oesophageal Varices } \\
\text { (grade) }\end{array}$ & $\begin{array}{c}\text { Gastric Varices } \\
\text { (grade) }\end{array}$ \\
\hline 1 & 14 & Female & 41,000 & 19 & 19 & IV & GOV II \\
\hline 1 & 45 & Male & 43,000 & 21 & 20 & IV & GOV II \\
\hline \multicolumn{7}{|c|}{ Table VI. Table showing Distribution of Concomitant Gastric Varices and Oesophageal Varices } \\
\hline
\end{tabular}

There was no patient of isolated gastric varices in our study.

\section{DISCUSSION}

Cirrhosis is the most advanced form of liver disease and variceal haemorrhage is one of its lethal complications. Over half of the patients with cirrhosis will develop varices. The risk of recurrent bleeding is approximately $66 \%$ and usually occurs within 6 months of the initial bleeding episode. ${ }^{25}$

Cirrhotic patients with large oesophageal varices are at a high risk for bleeding, so efforts should be made to identify cirrhotic patients with large varices. ${ }^{25}$ In 1997, the American College of Gastroenterology (ACG) recommended screening endoscopy for cases with established cirrhosis who were candidates for medical therapy. ${ }^{26}$

One hundred patients were enrolled for this study and out of these 74 patients (74\%) were males and 26 patients (26\%) were females. Mean age of the patients was 47.5 years ranging from 14 to 85 years. It was observed that out of 100 patients in 19 patients (19\%) grade I oesophageal varices were seen, in 29 patients (29\%) grade II oesophageal varices were seen, in 27 patients (27\%) grade III oesophageal varices were seen, and in 25 patients (25\%) grade IV oesophageal varices were seen. Also, out of 100 patients, in 2 patients concomitant gastric varices were seen. A similar study was done by Abbasi et $\mathrm{al}^{27}$ in 102 patients to find out the correlation of thrombocytopaenia with grading of oesophageal varices in chronic liver disease patients. Out of 102 patients 7 patients had oesophageal varices grade I; 24 had grade II; 35 had grade III and 36 had grade IV. Gastric varices were detected only in 2 patients.

Our study demonstrated that thrombocytopaenia, presence of portal hypertension with splenomegaly and portal vein diameter are strong predictors of developing gastro-oesophageal varices in cirrhotic patients.

Earlier, the pathophysiology of thrombocytopaenia in liver disease was linked to the presence of hypersplenism, but now it has been discovered that thrombopoietin production is dependent on functioning liver cell mass and is responsible for reduced thrombopoiesis and consequently peripheral thrombocytopaenia. On the other hand, the presence of splenomegaly in cirrhotic patients is likely the result of vascular disturbance that are mainly linked to portal hypertension. ${ }^{27}$

In our study, it was observed that mean platelet count in grade I oesophageal varices was $142568.42 \pm 6640.369 / \mathrm{mm}^{3}$, in grade II oesophageal varices was $109272.41 \pm$ $9567.16 / \mathrm{mm}^{3}$, in grade III oesophageal varices was 79288.89 $\pm 5506.94 / \mathrm{mm}^{3}$ and in grade IV oesophageal varices was $45156.00 \pm 7032.43 / \mathrm{mm}^{3}$. Platelet count showed a highly statistical significant inverse correlation with the grading of oesophageal varices, which is in agreement with Thomopulos et $\mathrm{al}^{24}$ who reported that platelet count was the only common factor found to be significant predictor of both small and large varices.
Splenomegaly and portal vein diameter are also reliable predictors of the presence of oesophageal varices. In our study, the mean spleen size of the patients with grade I oesophageal varices was $12.05 \pm 0.67 \mathrm{~cm}$ with grade II oesophageal varices was $14.33 \pm 0.93 \mathrm{~cm}$ with grade III oesophageal varices was $16.35 \pm 1.03 \mathrm{~cm}$ and with grade IV oesophageal varices was $19.10 \pm 1.16 \mathrm{~cm}$, which showed a statistical significant direct correlation with the presence of oesophageal varices which is in agreement with Chalasani et $\mathrm{al}^{28}$ who reported that splenomegaly is recognised as one of the diagnostic signs of cirrhosis and portal hypertension. In a study carried out by Mandal et $\mathrm{al}^{29}$ it has been shown that grading of oesophageal varices also correlates with spleen size and portal vein diameter. Sharma and Agarwal ${ }^{30}$ in their study had noted that clinically palpable spleen was associated with high-grade varices; however, they did not measure the splenic size radiologically. Farooqi et $\mathrm{al}^{31}$ also found out that platelet count of $<65 \times 10^{3} / \mu \mathrm{L}$, serum albumin $<2.2 \mathrm{~g} / \mathrm{dL}$ and portal vein diameter of $>13 \mathrm{~mm}$ are independent and significant predictors of oesophageal varices on endoscopy.

It was observed in our study that the mean portal vein diameter of the patients with grade I oesophageal varices was $13.16 \pm 0.61 \mathrm{~mm}$, with grade II oesophageal varices was $14.59 \pm 0.56 \mathrm{~mm}$, with grade III oesophageal varices was $16.39 \pm 0.69 \mathrm{~mm}$ and with grade IV oesophageal varices was $19.02 \pm 0.99 \mathrm{~mm}$, which shows a statistical significant direct correlation between Portal vein diameter and the presence of oesophageal varices which is in accordance with the study done by Sarwar et al $^{20}$ who postulated that portal vein diameter more than $11 \mathrm{~mm}$ on ultrasonography is independently associated with the presence of oesophageal varices.

Hence, it is concluded from our study that gastrooesophageal varices in cirrhotic patients has a direct correlation with portal vein diameter and splenomegaly and an inverse correlation with thrombocytopaenia.

Hence, the inference is drawn that with increase in size of gastro-oesophageal varices, the size of portal vein and spleen also increases and the patient is likely to develop thrombocytopaenia.

\section{CONCLUSION}

It is concluded from our study that,

1. Portal vein diameter increases with development of gastro-oesophageal varices.

2. Spleen size increases with formation of gastrooesophageal varices.

3. Platelet count decreases with the development of gastrooesophageal varices.

4. There is a positive correlation between portal vein diameter and splenomegaly with gastro-oesophageal varices and an inverse relationship between thrombocytopaenia and gastro-oesophageal varices. 


\section{REFERENCES}

[1] Arey LB, Burrows W, Greenhill JP, et al. Dorland's illustrated medical dictionary. 23 $3^{\text {rd }}$ edn. Philadlphia: WB Saunders Company 1962: p. 286.

[2] Anthony $\mathrm{PP}$, Ishak $\mathrm{KG}$, Nayak $\mathrm{NC}$, et al. The morphology of cirrhosis. Recommendations on definition, nomenclature, and classification by a working group sponsored by the World Health Organization. J Clin Pathol 1978;31(5):395-414.

[3] Conn HO. Cirrhosis. In: Schiff L. edr. Diseases of the liver. $4^{\text {th }}$ edn. Philadelphia: JB Lippincott Company 1975: p. 833.

[4] Guha NI, Iredale JP. Clinical and diagnostic aspects of cirrhosis. In: Rodés J, Benhamou JP, Blei A, et al. eds. Textbook of hepatology from basic science to clinical practice. $3^{\text {rd }}$ edn. Oxford: Blackwell Publishing 2007:604-22.

[5] Podolsky DK, Isselbacher KJ. Cirrhosis and alcoholic liver disease and major complications of cirrhosis. In: Fauce AS, Braunwald E, Isselbacher KJ, et al. eds. Harrison's Principles of internal medicine. 14th $\mathrm{edn}$. McGraw-Hill 1998:1704-17.

[6] De Franchis R, Primignani M. Natural history of portal hypertension in patients with cirrhosis. Clin Liver Disease 2001;5(3):645-63.

[7] Casado M, Bosch J, Garcia-Pagan JC, et al. Clinical events after transjugular intrahepatic portosystemic shunt: correlation with hemodynamic findings. Gastroenterology 1998;114(6):1296-1303.

[8] Gacia-Tsao G, Groszmann RJ, Fisher RL, et al. Portal pressure, presence of gastroesophageal varices and variceal bleeding. Hepatology 1985;5(3):419-24.

[9] Rigau J, Bosch J, Bordas JM, et al. Endoscopic measurement of variceal pressure in cirrhosis correlation with portal pressure and variceal hemorrhage. Gastroenterology 1989;96(3):873-80.

[10] Gupta TK, Tourner M, Chung MK, et al. Endothelial dysfunction and decreased production of nitric oxide in the intrahepatic microcirculation of cirrhotic rats. Hepatology 1998;28(4):926-31.

[11] De Franchis R, Dell'Era A. Non-invasive diagnosis of cirrhosis and the natural history of its complications. Best Pract Res Clin Gastroenterol 2007;21(1):3-18.

[12] Rigo GP, Merighi A, Chahin NJ, et al. A prospective study of the ability of three endoscopic classifications to predict hemorrhage from esophageal varices. Gastrointest Endosc 1992;38(4):425-9.

[13] Shabestari AA, Nikoukar E, Bakhshandeh H. Hepatic doppler ultrasound in assessment of the severity of esophageal varices in cirrhotic patients. Iran J Radiol Spring 2007;4(3):151-8.

[14] Kajiwara E, Akagi K, Azuma K, et al. Evidence for an immunological pathogenesis of thrombocytopenia in chronic liver disease. Am J Gastroenterol 1995;90(6): 962-6.

[15] Bosch J, Navasa M, Garcia-Pagan JC. Portal hypertension. Med Clin North Am 1989;73:931-53.

[16] González-Ojeda A, Cervantes-Guevara G, ChávezSanchez M, et al. Platelet count/spleen diameter ratio to predict esophageal varices in Mexican patients with hepatic cirrhosis. WJG 2014;20(8):2079-84.
[17] Shah VH, Kamath PS. Portal hypertension and gastrointestinal bleeding. In: Sleisenger and Fordtran's gastrointestinal and liver disease. Vol 2. $9^{\text {th }}$ edn. Elsevier 2009:1496-7.

[18] Paquet KJ. Prophylactic endoscopic sclerosing treatment of esophageal wall in varices: a prospective controlled trial. Endoscopy 1982;14(1):4-5.

[19] Sarin SK, Preimignani M, Agarwal SR. Gastric varices. In: Defranchis R. edr. Portal hypertension, proceeding of the third Baveno International Consensus Workshop on definitions, methodology and therapeutic strategies. Oxford: Blackwell Science 2001:576-9.

[20] Sarwar S, Khan AA, Alam A. Non-endoscopic prediction of presence of esophageal varices in cirrhosis. J Coll Physicians Surg Pak 2005;15(9):52831.

[21] Dib N, Konate A, Obesti F, et al. Non-invasive diagnosis of portal hypertension in cirrhosis. Application to the primary prevention of varices. Gastroenterol Clin Biol 2005;29(10):975-87.

[22] Sarangapani A, Shanmugam C, Kalyanasundaram M, et al. Noninvasive prediction of large esophageal varices in chronic liver disease patients. Saudi J Gastroenterol 2010;16(1):38-42.

[23] Sotoudehmanesh R, Ainechi S, AliAsgari A, et al. Endoscopic ultrasonography in patients with chronic liver disease: a case control study. Govaresh 2012;16(4):270-4.

[24] Schwarzenberger E, Meyer T, Golla V, et al. Utilization of platelet count /spleen diameter ratio in predicting the presence of esophageal varices in patients with cirrhosis. J Clin Gastroenterol 2010;44(2):146-50.

[25] Zaman A, Becker T, Lopidus J, et al. Risk factors for the presence of varices in cirrhotic patients without a history of variceal hemorrhage. Archives of Internal Medicine 2001;161(21):2564-70.

[26] The North Italian Endoscopic Club for the Study and Treatment of Esophageal Varices. Prediction of the first variceal hemorrhage in patients with cirrhosis of the liver and esophageal varices: a prospective multicenter study. N Engl J Med 1988;319(15):983-9.

[27] Abbasi A, Butt N, Bhutto AR, et al. Correlation of thrombocytopenia with grading of esophageal varices in chronic liver disease patients. Journal of the College of Physicians and Surgeons Pakistan 2010;20(6):36972.

[28] Chalasani N, Imperiale TF, Ismail A, et al. Predictors of large esophageal varices in patients with cirrhosis. Am J Gastroenterol 1999;94(11):3285-91.

[29] Mandal L, Mandal SK, Bandyopadhyay D, et al. Correlation of portal vein diameter and splenic size with gastro-oesophageal varices in cirrhosis of liver. JIACM 2011;12(4):266-70.

[30] Sharma SK, Aggarwal R. Prediction of large esophageal varices in patients with cirrhosis of the liver using clinical, laboratory and imaging parameters. J Gastroenterol Hepatol 2007;22(11):1909-15.

[31] Farooqi JI, Ahmed H, Ikramullah Q, et al. Predictors of esophageal varices in patients of liver cirrhosis. JPMI 2007;21(01):60-4. 